$\underline{\text { Review Articles }}$

\title{
Epidemiology of Prothrombin G20210A Mutation in the Mediterranean Region.
}

\author{
Mehrez M. Jadaon
}

Department of Medical Laboratory Sciences, Faculty of Allied Health Sciences, Kuwait University, Kuwait

Correspondence to: Mehrez M. Jadaon. Department of Medical Laboratory Sciences, Faculty of Allied Health Sciences, Kuwait University, P.O. Box 31470 - Sulaibekaht 90805 - Kuwait. Tel.: (965) 6664 3485 Fax: (965) 2498 3835. Email: mehrez@hsc.edu.kw mehrezmls99@yahoo.com

Competing interests: The authors have declared that no competing interests exist.

Published: November 28, 2011

Received: October 1, 2011

Accepted: October 7, 2011

Mediterr J Hematol Infect Dis 2011, 3(1): e2011054, DOI 10.4084/MJHID.2011.054

This article is available from: http://www.mjhid.org/article/view/9310

This is an Open Access article distributed under the terms of the Creative Commons Attribution License (http://creativecommons.org/licenses/by/2.0), which permits unrestricted use, distribution, and reproduction in any medium, provided the original work is properly cited.

Abstract. There are many genetic and acquired risk factors that are known to cause venous thromboembolic disorders (VTE). One of these is the Prothrombin G20210A mutation, which has been identified in 1996. Prothrombin G20210A mutation causes higher levels of the clotting factor prothrombin in the blood of carriers, which creates a higher tendency towards blood clotting (hypercoagulability), and therefore the carriers become at higher risk of developing VTE. High prevalence of Prothrombin G20210A mutation was reported in Caucasian populations, but the prevalence was almost absent in non-Caucasians. That was most obvious in countries of South Europe and the Mediterranean region. This review article discusses Prothrombin G20210A mutation, how it causes VTE, the origin of the mutation, and its distribution worldwide with special concentration on the Mediterranean area.

Introduction. Venous thromboembolic disorders (VTE) are serious disorders accounting for high morbidity and mortality rates with an annual incidence of $1 / 1000 .^{1-4}$ Many genetic and acquired risk factors were identified to cause VTE including Factor V Leiden mutation, genetic deficiencies of proteins $\mathrm{C}, \mathrm{S}$ and antithrombin, lupus anticoagulants, pregnancy, use of contraceptives, major surgeries, cancer, inflammations, and Prothrombin G20210A mutation. This review article focuses on Prothrombin G20210A mutation, its pathophysiology, prevalence and origin, with a special concentration on this mutation in the Mediterranean region.
Role of Prothrombin in the Coagulation System. In case of blood vessel injury, blood coagulation is initiated through a cascade of chemical reactions to form a blood clot to block the injured blood vessel and prevent blood loss. Several enzymes and proteins, generally known as blood clotting factors, are involved in blood coagulation, a very important one is thrombin (clotting factor II). Thrombin is usually produced in the liver in an inactive form called prothrombin, which circulates in the blood until being activated in case of injury. Potrhombin gets activated into thrombin by another clotting factor called activated factor X. The main function of thrombin is to convert fibrinogen (clotting factor I) into a fibrin clot that blocks the 
injured blood vessel. In fact, thrombin is a very robust enzyme that plays a major role in the coagulation system by activating many clotting factors and other elements of the coagulation system like the blood platelets. Thrombin is usually under careful monitoring by an inhibitor called antithrombin (AT), which downregulates thrombin after clot formation and prevents accidental formation of thrombin in sites away from injured vessels. ${ }^{5,6}$ This is very crucial to prevent the formation of unnecessary clots inside intact blood vessels. The formation of such intravascular clots predisposes to the development of VTE.

Prothrombin G20210A Mutation. Because of the importance of thrombin in the coagulation system, genetic or acquired deficiency of prothrombin usually causes impaired clotting and therefore bleeding problems (hemophilia). On the contrary, if prothrombin is produced in higher quantities in the blood, this is expected to cause an increased tendency towards blood clotting, a condition known as "hypercoagulability", which usually manifests clinically as VTE. It has been demonstrated that prothrombin levels more than $115 \%$ of the normal level have 2-fold increased risk of developing VTE. ${ }^{7}$ Poort et al (1996) performed an extensive DNA sequencing on the prothrombin gene (on chromosome 11) for patients with unexplained VTE. ${ }^{7}$ They found a single missense mutation (guanine to adenine; $\mathrm{G} \rightarrow \mathrm{A}$ ) at nucleotide position 20210, which is present in the $3^{\prime}$ untranslated region of the prothrombin gene. This Prothrombin G20210A mutation is present outside the coding region for prothrombin, and hence it does not affect the actual structure of the prothrombin molecule and it does not affect its function as a strong clotting factor when activated into thrombin. However, Prothrombin G20210A mutation was found to cause elevated levels of blood prothrombin (by one-third above normal; $133 \%$ ), which is more than the extra $15 \%$ needed to develop VTE. Also, it has been proven that Prothrombin G20210A mutation leads to increased mRNA and protein expression for prothrombin. ${ }^{8}$

Table 1. Prevalence of Prothrombin G20210A mutation in different populations and countries worldwide.

\begin{tabular}{|c|c|c|c|c|}
\hline & Region/Country & $\begin{array}{c}\text { VTE } \\
\text { patients \% }\end{array}$ & $\begin{array}{c}\text { Healthy } \\
\text { population \% }\end{array}$ & References \\
\hline \multirow{6}{*}{ Caucasians } & $\begin{array}{l}\text { North Europe } \\
\text { (UK, Ireland, Sweden, Finland, Belarus, Russia, } \\
\text { Denmark, Netherlands, Poland, Germany) }\end{array}$ & 6.5 & $0-2.9$ & $16-26$ \\
\hline & $\begin{array}{l}\text { South Europe } \\
\text { (France, Austria, Spain, Switzerland, Hungary, Italy, } \\
\text { Slovenia, Croatia, Serbia, Greece, Turkey, Cyprus) }\end{array}$ & $2.7-17.2$ & $0.7-8.0$ & $\begin{array}{l}16,17 \\
28-67\end{array}$ \\
\hline & USA & $3.2-9.7$ & $1.3-5.0$ & $68-71$ \\
\hline & Brazil & --- & 1.7 & 72 \\
\hline & Australia & -"-- & 4.3 & 73 \\
\hline & 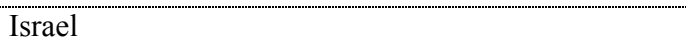 & "--- & 4.0 & 74 \\
\hline \multirow{5}{*}{ Africans } & $\begin{array}{l}\text { Ivory Coast, Central Africa Republic, Madagascar, } \\
\text { Kenya, Mali }\end{array}$ & --- & 0 & 75 \\
\hline & Zaire, Cameron & "--- & 0 & 72 \\
\hline & USA & $1.1-2.2$ & $0-0.3$ & $\begin{array}{l}68,69,70 \\
71,76,77\end{array}$ \\
\hline & Israel & --- & 0 & 74 \\
\hline & Brazil & "--- & 0 & 72 \\
\hline Hispanics & USA & 8.9 & $0.5-2.4$ & 68,70 \\
\hline $\begin{array}{l}\text { Mexican } \\
\text { Mestizos }\end{array}$ & Mexico & $13.5-15.0$ & & 78,79 \\
\hline \multirow{8}{*}{ Asians } & China & 0 & 0 & 80,81 \\
\hline & Japan & --- & 0 & $72,82,83$ \\
\hline & Korea & 0 & 0 & $68,84,85$ \\
\hline & Mongolia & --- & 0 & 75 \\
\hline & Taiwan & 0 & 0 & $75,86,87$ \\
\hline & $\begin{array}{l}\text { Southeast Asia } \\
\text { (Indonesia, Burma, Cambodia, Thailand, Taiwan, } \\
\text { Vietnam, Hong Kong }\end{array}$ & --- & 0 & 75 \\
\hline & India & 0 & $0-0.6$ & $68,75,88-92$ \\
\hline & Pakistan, Bangladesh & --- & 0 & 88 \\
\hline \multirow{4}{*}{$\begin{array}{l}\text { Native } \\
\text { Americans } \\
\text { (Amerind- } \\
\text { ians) }\end{array}$} & USA & --- & 0 & 68 \\
\hline & Canada & ---" & 0 & 75 \\
\hline & Brazil & --- & 0 & 72,75 \\
\hline & Mexico & --- & 0 & 75 \\
\hline $\begin{array}{l}\text { Australian } \\
\text { Aboriginals }\end{array}$ & Australia & --- & 0 & 93 \\
\hline Austral-asians & Papua New Guinea, Vanuatu, Tonga, Micronesia & --- & 0 & 75 \\
\hline
\end{tabular}


Moreover, increased prothrombin levels may lead to an increase in a protein called thrombin-activatable fibrinolysis inhibitor (TAFI), which is an inhibitor of the fibrinolysis process. Fibrinolysis is the process by which the blood removes clots. Therefore, an increase in TAFI may disturb the fibrinolysis process and therefore allow for accumulation of clots leading to VTE. ${ }^{9,10}$ This is another possible pathophysiological pathway of causing VTE in cases having Prothrombin G20210A mutation with elevated TAFI. All these findings may explain why Prothrombin G20210A mutation may cause hypercoagulability and an increased risk of developing VTE. Such increased risk was reported to be 2 to 4 -fold. ${ }^{7,11-15}$

Prevalence of Prothrombin G20210A mutation. The prevalence of Prothrombin G20210A mutation in European Caucasians was found to be roughly $3-17 \%$ in patients with VTE and 1-8\% in healthy controls. That was also true in Caucasians living outside Europe like in the USA, Australia, Brazil and Israel (Table 1). It may be noticed here that the prevalence of Prothrombin G20210A mutation is higher in the Southern European countries than in the Northern countries, in spite of presence of overlapping between the North and South. On the other hand, Prothrombin G20210A mutation was found to be very rare or even absent in Asian and African populations, and in native populations of America (Amerindians) and Australia (Table 1). This was also true when these populations were studied in countries outside their origin like African Americans and Asians living in the USA. The only exception to the above observations is the high prevalence reported in Hispanics and Mexican Mestizos; the latter are descendants of mixed marriages between Europeans and Amerindians. The presence of European genes in such populations may explain the high prevalence of Prothrombin G20210A mutation in these.

High prevalence of Prothrombin G20210A mutation was also reported in populations living close to Europe, namely countries of the Middle East and North Africa. In fact, the prevalence in these countries was very comparable with the prevalence reported in Southern European countries. Therefore, the countries present on the coasts of the Mediterranean Sea, including Southern Europe, may be grouped together sharing the same prevalence of Prothrombin G20210A mutation (Table 2). These countries, 20 in total, have a prevalence of $3-24 \%$ in patients with VTE and 1-12\% in the general population. No reports could be found in Malta, Syria, Bosnia, Albania and Macedonia. The highest prevalence was found by a study in Egypt in patients with VTE, but the highest among the general populations (healthy controls) was in Palestinians living in Israel (Israeli Arabs). Unfortunately, there were no reports on the prevalence in Palestinian patients with VTE, which kight be higher than the one reported in Egypt, noting that Egypt and Palestine are geographically neighbours.

Table 2. Prevalence of Prothrombin G20210A mutation in the Mediterranean countries.

\begin{tabular}{lccc}
\hline Country & $\begin{array}{c}\text { VTE } \\
\text { patients \% }\end{array}$ & $\begin{array}{c}\text { General healthy } \\
\text { population \% }\end{array}$ & References \\
\hline Lebanon & 19.2 & $1.3-3.6$ & $94-99$ \\
Palestine & --- & $6.5-11.7$ & 74,100 \\
Egypt & 23.75 & 3.33 & 101 \\
Tunisia & 3.2 & $0-7.4$ & $74,79-$ \\
& & & $99,102-105$ \\
Libya & --- & 2.2 & 74 \\
Algeria & 6.0 & 1.8 & 106 \\
Morocco & --- & $2.4-5.5$ & $74,107-109$ \\
Spain & $2.7-17.2$ & $2.9-6.5$ & $31-35$ \\
France & 4.6 & $1.0-3.1$ & $36-39$ \\
Italy & $4.3-15.9$ & $2.3-5.7$ & $40-47$ \\
Slovenia & $5.8-11.3$ & $3.1-4.8$ & 48,49 \\
Croatia & $8.0-8.3$ & $2.5-4.0$ & $50-53$ \\
Serbia & 11.4 & $2.3-6.0$ & $54-56$ \\
Greece & $6.8-10.1$ & $2.0-2.7$ & $57-61$ \\
Turkey & $4.0-10.5$ & $0.7-8.0$ & $62-65$ \\
Cyprus & --- & $2.0-7.8$ & 66,67 \\
\hline
\end{tabular}

Origin of Prothrombin G20210A mutation. The highest prevalence of Prothrombin G20210A mutation in European Caucasians brought up speculations that Prothrombin G20210A mutation might have occurred as a single event in a single Caucasian ancestor and that the current Caucasian carriers of the mutation should have descended from that proposed grandparent. This assumption was supported by a molecular study that found a haplotype to be associated with more than two third of carriers of the mutation compared to one third of non-carriers. This suggests a founder effect, and the mutation was estimated to occur around 24 thousand years ago after the divergence of Africans from Non-Africans and Caucasoids from Mongoloids. ${ }^{110}$ It is tempting to explore this founder haplotype in non-Caucasian carriers of the Prothrombin G20210A mutation in the Middle East and North Africa to see if this founder effect occurred there too. In addition, it may be interesting to study this mutation in the Basque population (in France and Spain), who is thought to be the oldest ethnic group living in Europe. Finding or not finding the mutation in this population may give a hint on the origin of the mutation and to know if it occurred inside or outside Europe. Also, if a future study can prove that Palestinian patients with VTE have the highest prevalence of Prothrombin G20210A mutation (like the general Palestinian population), then this region (Palestine/Israel) may be the place where the mutation has occurred and then spread to Europe and other parts of the Mediterranean region. This region has witnessed a lot of mankind 
movements since the old ages, since the Neolithic period, and then the Phoenicians who appeared in Lebanon and then cruised to many cities on the Mediterranean coast, followed by the Roman and Greek civilizations, and more recently the Crusaders and Ottomans. Therefore, it is encouraging to try to find certain genetic or chromosomal markers that can help in following the migratory history of manhood in the Mediterranean region which may give a final approach towards determining exactly where the

\section{References:}

1. Dahlbäck B. Resistance to activated protein C, the Arg506 to Gln mutation in the factor $\mathrm{V}$ gene, and venous thrombosis. Functional tests and DNA-based assays. Pros and Cons. Thromb Haemost. 1995;73:739-742 PMid:7482395

2. Rees DC, Cox M, Clegg JB. World distribution of factor V Leiden. $\quad$ Lancet. 1995;346:1133-1134 http://dx.doi.org/10.1016/S0140-6736(95)91803-5

3. Ridker PM, Miletich JP, Hennekens CH, Buring JE. Ethnic distribution of Factor V Leiden in 4047 men and women. Implications for venous thrmoboembolism screening. JAMA. 1997;277:1305-1307 http://dx.doi.org/10.1001/jama.277.16.1305

4. Zivelin A, Griffin JH, Xu X, Pabinger I, Samama M, Conard J, Brenner B, Eldor A, Seligsohn U. A single genetic origin for a common Caucasian risk factor for venous thrombosis. Blood. 1997;89:397-402 PMid:9002940

5. Lane DA, Mannucci PM, Bauer KA, Bertina RM, Bochkov NP, Boulyjenkov V, Chandy M, Dahlbäck B, Ginter EK, Miletich JP, Rosendaal FR, Seligsohn U. Inherited thrombophilia: Part 1. Thromb Haemost. 1996;76:651-662 PMid:8950768

6. Davie EW. Biochemical and molecular aspects of the coagulation cascade. Thromb Haemost. 1995;74:1-6 PMid:8578439

7. Poort SR, Rosendaal FR, Reitsma PH, Bertina RM. A common genetic variation in the 3 '-untranslated region of the prothrombin gene is associated with elevated plasma prothrombin levels and an increase in venous thrombosis. Blood. 1996;88:3698-3703 PMid:8916933

8. Ceelie H, Spaargaren-van Riel CC, Bertina RM, Vos HL. G20210A is a functional mutation in the prothrombin gene; effect on protein levels and 3 '-end formation. J Thromb Haemost. 2004;2:119-127 836.2003.00493.x PMid:14717975

9. Meltzer ME, Lisman T, de Groot PG, Meijers JC, le Cessie S, Doggen CJ, Rosendaal FR. Venous thrombosis risk associated with plasma hypofibrinolysis is explained by elevated plasma levels of TAFI and PAI-1. Blood. 2010;116:113-121 http://dx.doi.org/10.1182/blood-2010-02-267740 PMid:20385790

10. Miljić P, Heylen E, Willemse J, Djordjević V, Radojković D, Colović M, Elezović I, Hendriks D. Thrombin activatable fibrinolysis inhibitor (TAFI): a molecular link between coagulation and fibrinolysis. Srp Arh Celok Lek. 2010;138:74-78 PMid:20229688

11. Bertina, RM. Factor V Leiden and other coagulation factor mutations affecting thrombotic risk. $\mathrm{Cl}$ Chem. 1997:43:16781683 PMid:9299960

12. Koeleman BPC, Reitsma PH, Bertina RM. Familial thrombophilia: a complex genetic disorder. Semin Hematol. 1997;34:256-264 PMid:9241710

13. Hillarp A, Zöller B, Svensson PJ, Dahlbäck B. The 20210A allele of the prothrombine gene is a common risk factor among Swedish outpatients with verified deep venous thrombosis. Thromb Haemost. 1997;78:990-992 PMid:9308741

14. Alhenc-Gelas M, Le Cam-Duchez V, Emmerich J, Frebourg T, Fiessinger JN, Barg JY, Aiach M. The A20210 allele of the prothrombin gene is not frequently associated with the factor $\mathrm{V}$ Arg506 to Gln mutation in thrombophilic families. Blood. 1997;96:1711

15. Dahlbäck B. Advances in understanding pathogenic mechanisms mutation has occurred first and how it spread all over the Mediterranean region.

Conclusions. The prevalence of Prothrombin G20210A mutation differs in different countries and ethnic groups, being highest in Caucasians, especially those in the Southern Europe, and in the Mediterranean region. Further studies are needed to verify where exactly has the mutation occurred first and how it was carried to other parts of the world. of thrombophilic disorders. Blood. 2008;112:19-27 http://dx.doi.org/10.1182/blood-2008-01-077909 PMid:18574041

16. Rosendaal FR, Doggen CJ, Zivelin A, Arruda VR, Aiach M, Siscovick DS, Hillarp A, Watzke HH, Bernardi F, Cumming AM, Preston FE, Reitsma PH. Geographic distribution of the $20210 \mathrm{G}$ to A prothrombin variant. Thromb Haemost. 1998;79:706-708 PMid:9569177

17. Bykowska K, Vertun-Baranowska B, Windyga J, Łopaciuk S. Prevalence of G20210A prothrombin gene mutation in Poland. Pol Arch Med Wewn. 2000;104:729-733 PMid:11434083

18. McColl MD, Ellison J, Reid F, Tait RC, Walker ID, Greer IA. Prothrombin $20210 \diamond \mathrm{A}$, MTHFR C677T mutations in women with venous thromboembolism associated with pregnancy. BJOG. 2000;107:565-569 http://dx.doi.org/10.1111/j.14710528.2000.tb13281.x

19. Wramsby ML, Sten-Linder M, Bremme K. Primary habitual abortions are associated with high frequency of factor $\mathrm{V}$ Leiden $\begin{array}{llll}\text { mutation. } & \text { Fertil } & \text { Steril. } & \text { 2000;74:987-991 }\end{array}$ http://dx.doi.org/10.1016/S0015-0282(00)01545-4

20. Vossen CY, Hoffmeister M, Chang-Claude JC, Rosendaal FR, Brenner H. Clotting factor gene polymorphisms and colorectal cancer risk. J Clin Oncol. 2011;29:1722-1727 http://dx.doi.org/10.1200/JCO.2010.31.8873 PMid:21422408

21. Petäjä J, Hiltunen L, Fellman V. Increased risk of intraventricular hemorrhage in preterm infants with thrombophilia. Pediatr Res. 2001;49:643-646 http://dx.doi.org/10.1203/00006450-200105000-00006

22. Avdonin PV, Kirienko AI, Kozhevnikova LM, Shostak NA, Babadaeva NM, Leont'ev SG, Petukhov EB, Kubatiev AA, Savel'ev VS. C677T mutation in methylentetrahydrofolatereductase gene in patients with venous thromboses from the central region of Russia correlates with a high risk of pulmonary artery thromboembolism. Ter Arkh. 2006;78:70-76

23. Lipay NV, Dmitriev VV, Borisenok MB. Thrombotic complications during cancer treatment in children. Exp Oncol. 2007;29:231-235 PMid:18004248

24. Keenan C, Livingstone WJ, White B, Mynett-Johnson L, Cusack S, Lawler M, Smith OP. Prevalence of the prothrombin G20210A mutation in the Irish populations: use of a novel polymerase chain reaction approach. Blood Coagul Fibrinolysis. 2000;11:669-672 PMid:7482395

25. Pherwani AD, Winter PC, McNamee PT, Patterson CC, Hill CM, Connolly JK, Maxwell AP. Is screening for factor V Leiden and prothrombin G20210A mutations in renal transplantation worthwhile? Results of a large single-center U.K. study. Transplantation. 2003;76:603-605

26. Jensen MK, de Nully Brown P, Thorsen S, Hasselbalch HC. Frequent occurrence of anticardiolipin antibodies, Factor V Leiden mutation, and perturbed endothelial function in chronic myeloproliferative disorders. Am J Hematol. 2002;69:185-191

27. Silingardi M, Salvarani C, Boiardi L, Accardo $\mathrm{P}$, Iorio A, Olivieri I, Cantini F, Salvi F, La Corte R, Triolo G, Ciccia F, Ghirarduzzi A, Filippini D, Paolazzi G, Iori I. Factor V Leiden and prothrombin gene G20210A mutations in Italian patients with Behçet's disease and deep vein thrombosis. Arthritis Rheum. 2004;51:177-183 PMid:9002940

28. Balogh I, Póka R, Losonczy G, Muszbek L. High frequency of 
factor V Leiden mutation and prothrombin 20210A variant in Romanies of Eastern Hungary. Thromb Haemost. 1999;82:15551556 PMid: 8950768

29. Laczkovics C, Grafenhofer H, Kaider A, Quehenberger P, Simanek R, Mannhalter C, Lechner K, Pabinger I. Risk of recurrence after a first venous thromboembolic event in young women. Haematologica. 2007;92:1201-1207 PMid:8578439

30. Lalouschek W, Schillinger M, Hsieh K, Endler G, Tentschert S, Lang W, Cheng S, Mannhalter C. Matched case-control study on factor V Leiden and the prothrombin G20210A mutation in patients with ischemic stroke/transient ischemic attack up to the age of 60 years. Stroke. 2005;36:1405-1409 PMid:8916933

31. Francès F, Portolès O, Gabriel F, Corella D, Sorlí JV, Sabater A, Alfonso JL, Guillén M. Factor V Leiden (G1691A) and prothrombin-G20210A alleles among patients with deep venous thrombosis and in the general population from Spain. Rev Med Chil. 2006;134:13-20 PMid:14717975

32. González Ordóñez AJ, Medina Rodríguez JM, Fernández Alvarez CR, Sánchez García J, Martín Sánchez L, Coto García E, Alvarez Martínez MV. 20210A mutation of the prothrombin and venous thromboembolism gene. Sangre (Barc). 1999;44:1318 PMid:20385790

33. Alvarez A, Barroso A, Robledo M, Arranz E, Outeiriño J, Benítez J. Prevalence of Factor V Leiden and the G20210A mutation of the prothrombin gene in a random group of patients with thrombotic episodes. Sangre (Barc). 1999;44:7-12 PMid:20229688

34. Souto JC, Coll I, Llobet D, del Río E, Oliver A, Mateo J, Borrell M, Fontcuberta J. The prothrombin 20210A allele is the most prevalent genetic risk factor for venous thromboembolism in the Spanish population. Thromb Haemost. 1998;80:366-369 PMid:9299960

35. Roldan V, Lecumberri R, Muñoz-Torrero JF, Vicente V, Rocha E, Brenner B, Monreal M; RIETE Investigators. Thrombophilia testing in patients with venous thromboembolism. Findings from the RIETE registry. Thromb Res. 2009;124:174-177 PMid:9241710

36. Leroyer C, Mercier B, Oger E, Chenu E, Abgrall JF, Férec C, Mottier D. Prevalence of 20210 A allele of the prothrombin gene in venous thromboembolism patients. Thromb Haemost. 1998;80:49-51 PMid:9308741

37. Mazoyer E, Ripoll L, Gueguen R, Tiret L, Collet JP, dit Sollier CB, Roussi J, Drouet L; FITENAT Study Group. Prevalence of factor V Leiden and prothrombin G20210A mutation in a large French population selected for nonthrombotic history: geographical and age distribution. Blood Coagul Fibrinolysis. 2009;20:503-510

38. Pasquier E, Bohec C, Mottier D, Jaffuel S, Mercier B, Férec C, Collet M, De Saint Martin L. Inherited thrombophilias and unexplained pregnancy loss: an incident case-control study. J Thromb Haemost. 2009;7:306-311 PMid:18574041

39. Reny JL, Alhenc-Gelas M, Fontana P, Bissery A, Julia PL, Fiessinger JN, Aiach M, Emmerich J. The factor II G20210A gene polymorphism, but not factor V Arg506Gln, is associated with peripheral arterial disease: results of a case-control study. J Thromb Haemost. 2004;2:1334-1340 PMid:9569177

40. Martinelli I, Bucciarelli P, Margaglione M, De Stefano V, Castaman G, Mannucci PM. The risk of venous thromboembolism in family members with mutations in the genes of factor $\mathrm{V}$ or prothrombin or both. $\mathrm{Br} \mathrm{J}$ Haematol. 2000;111:1223-1239 PMid:11434083

41. Martinelli I, Taioli E, Cetin I, Marinoni A, Gerosa S, Villa MV, Bozzo M, Mannucci PM. Mutations in coagulation factors in women with unexplained late fetal loss. $N$ Engl J Med. 2000;343:1015-1018

42. Margaglione M, Brancaccio V, De Lucia D, Martinelli I, Ciampa A, Grandone E, Di Minno G. Inherited thrombophilic risk factors and venous thromboembolism: distinct role in peripheral deep venous thrombosis and pulmonary embolism. Chest. 2000;118:1405-411.

43. de Moerloose P, Reber G, Perrier A, Perneger T, Bounameaux H. Prevalence of factor V Leiden and prothrombin G20210A mutations in unselected patients with venous thromboembolism. $\mathrm{Br} \quad$ J Haematol. 2000;110:125-129 PMid:21422408

44. Silingardi M, Salvarani C, Boiardi L, Accardo P, Iorio A
Olivieri I, Cantini F, Salvi F, La Corte R, Triolo G, Ciccia F, Ghirarduzzi A, Filippini D, Paolazzi G, Iori I. Factor V Leiden and prothrombin gene $\mathrm{G} 20210 \mathrm{~A}$ mutations in Italian patients with Behçet's disease and deep vein thrombosis. Arthritis Rheum. 2004;51:177-183

45. Sottilotta G, Mammì C, Furlò G, Oriana V, Latella C, Trapani Lombardo V. High incidence of factor $\mathrm{V}$ Leiden and prothrombin G20210A in healthy southern Italians. Clin Appl Thromb Hemost. 2009;15:356-359

46. Tosetto A, Missiaglia E, Frezzato M, Rodeghiero F. The VITA project: prothrombin G20210A mutation and venous thromboembolism in the general population. Thromb Haemost. 1999;82:1395-1398 PMid:18004248

47. Cattaneo M, Chantarangkul V, Taioli E, Santos JH, Tagliabue L. The G20210A mutation of the prothrombin gene in patients with previous first episodes of deep-vein thrombosis: prevalence and association with factor V G1691A, methylenetetrahydrofolate reductase $\mathrm{C} 677 \mathrm{~T}$ and plasma prothrombin levels. Thromb Res. 1999;93:1-8

48. Bedencic M, Bozic M, Peternel P, Stegnar M. Major and potential prothrombotic genotypes in patients with venous thrombosis and in healthy subjects from Slovenia. Pathophysiol Haemost Thromb. 2008;36:58-63

49. Zerjavic K, Zagradisnik B, Stangler Herodez S, Lokar L, Glaser Krasevac M, Kokalj Vokac N. Is the JAK2 V617F mutation a hallmark for different forms of thrombosis? Acta Haematol. 2010;124:49-56

50. Jukic I, Bingulac-Popovic J, Dogic V, Babic I, Culej J, Tomicic M, Vuk T, Sarlija D, Balija M. ABO blood groups and genetic risk factors for thrombosis in Croatian population. Croat Med J. 2009;50:550-558

51. Herak DC, Antolic MR, Krleza JL, Pavic M, Dodig S, Duranovic $\mathrm{V}$, Brkic $\mathrm{AB}$, Zadro R. Inherited prothrombotic risk factors in children with stroke, transient ischemic attack, or migraine. Pediatrics. 2009; 123:e653-660

52. Eterović D, Titlić M, Culić V, Zadro R, Primorac D. Lower contribution of factor V Leiden or G202104 mutations to ischemic stroke in patients with clinical risk factors: pairmatched case-control study. Clin Appl Thromb Hemost. 2007; 13:188-193

53. Coen D, Zadro R, Honović L, Banfić L, Stavljenić Rukavina A. Prevalence and association of the factor $\mathrm{V}$ Leiden and prothrombin G20210A in healthy subjects and patients with venous thromboembolism. Croat Med J. 2001;42:488-492

54. Kovac M, Mitic G, Mikovic Z, Djordjevic V, Savic O, Mandic V, Rakicevic LJ, Antonijevic N, Radojkovic D. Thrombophilia in women with pregnancy-associated complications: fetal loss and pregnancy-related venous thromboembolism. Gynecol Obstet Invest. 2010;69:233-238

55. Djordjevic V, Stankovic M, Brankovic-Sreckovic V, Rakicevic $\mathrm{L}$, Radojkovic D. Genetic risk factors for arterial ischemic stroke in children: a possible MTHFR and eNOS gene-gene interplay? J Child Neurol. 2009;24:823-827

56. Djordjevic V, Rakicevic LJ, Mikovic D, Kovac M, Miljic P, Radojkovic D, Savic A. Prevalence of factor V leiden, factor V cambridge, factor II G20210A and methylenetetrahydrofolate reductase C677T mutations in healthy and thrombophilic Serbian populations. Acta Haematol. 2004;112:227-229

57. Foka ZJ, Lambropoulos AF, Makris PE, Constantinidis TC, Kotsis A. High frequency of factor V Leiden and prothrombin G20210A mutations in Greek hemophiliacs. J Thromb Haemost. 2003;1:1116-1167

58. Hatzaki A, Anagnostopoulou E, Metaxa-Mariatou V, Melissinos C, Philalithis P, Iliadis K, Kontaxis A, Liberatos K, Pangratis N, Nasioulas G. The impact of heterozygosity for the factor $\mathrm{V}$ Leiden and factor II G20210A mutations on the risk of thrombosis in Greek patients. Int Angiol. 2003;22:79-82 PMid:7482395

59. Zalavras ChG, Giotopoulou S, Dokou E, Mitsis M, Ioannou HV, Tsaousi C, Tzolou A, Kolaitis N, Vartholomatos G. Prevalence of the G20210A prothrombin gene mutation in Northwestern Greece and association with venous thromboembolism. Int Angiol. 2003;22:55-57

60. Agorastos T, Karavida A, Lambropoulos A, Constantinidis T, Tzitzimikas S, Chrisafi S, Saravelos H, Vavilis D, Kotsis A, Bontis J. Factor V Leiden and prothrombin G20210A mutations 
in pregnancies with adverse outcome. J Matern Fetal Neonatal Med. 2002;12:267-273

61. Antoniadi T, Hatzis T, Kroupis C, Economou-Petersen E Petersen MB. Prevalence of factor V Leiden, prothrombin G20210A, and MTHFR C677T mutations in a Greek population of blood donors. Am J Hematol. 1999;61:265-267 PMid:9002940

62. Tug E, Aydin H, Kaplan E, Dogruer D. Frequency of genetic mutations associated with thromboembolism in the Western Black Sea Region. Intern Med. 2011;50:17-21 PMid:8950768

63. Altinisik J, Ates O, Ulutin T, Cengiz M, Buyru N. Factor V Leiden, prothrombin G20210A, and protein C mutation frequency in Turkish venous thrombosis patients. Clin Appl Thromb Hemost. 2008;14:415-420 PMid:8578439

64. Irdem A, Devecioglu C, Batun S, Soker M, Sucakli IA. Prevalence of factor V Leiden and prothrombin G20210A gene mutation. Saudi Med J. 2005;26:580-583 PMid:8916933

65. Gurgey A, Haznedaroglu IC, Egesel T, Buyukasik Y, Ozcebe OI, Sayinalp N, Dundar SV, Bayraktar Y. Two common genetic thrombotic risk factors: factor $\mathrm{V}$ Leiden and prothrombin G20210A in adult Turkish patients with thrombosis. Am J Hematol. 2001;67:107-111 PMid:14717975

66. Xenophontos SL, Hadjivassiliou M, Ayrton N, Karagrigoriou A, Pantzaris M, Nicolaides AN, Cariolou MA. Spectrum and prevalence of prothrombotic single nucleotide polymorphism profiles in the Greek Cypriot population. Int Angiol. 2002;21:322-329 PMid:20385790

67. Angelopoulou K, Nicolaides A, Constantinou Deltas C. Prevalence of genetic mutations that predispose to thrombophilia in a Greek Cypriot population. Clin Appl Thromb Hemost. 2000;6:104-107 PMid:20229688

68. Hessner MJ, Luhm RA, Pearson SL, Endean DJ, Friedman KD, Montgomery RR. Prevalence of prothrombin G20210 A, factor V G1691 A (Leiden), and methyltetrahydrofolate reductase (MTHFR) C 677T in seven different populations determined by multiple allele-specific PCR. Thromb Haemost. 1999;81:733738 PMid:9299960

69. Dowling NF, Austin H, Dilley A, Whitsett C, Evatt BL, Hooper WC. The epidemiology of venous thromboembolism in Caucasians and African-Americans: the GATE Study. J Thromb Haemost. 2003;1:80-87 PMid:9241710

70. Tang Y, Sampson B, Pack S, Shah K, Yon Um S, Wang D, Wang T, Prinz M. Ethnic differences in out-of-hospital fatal pulmonary embolism. Circulation. 2011;123:2219-2225 PMid:9308741

71. Zakai NA, McClure LA. Racial Differences in Venous Thromboembolism. J Thromb Haemost. 2011; http://dx.doi.org/10. 1111/j.1538-7836.2011.04443.x

72. Franco RF, Santos SE, Elion J, Tavella MH, Zago MA. Prevalence of the G20210A polymorphism in the 3'-untranslated region of the prothrombin gene in different human populations. Acta Haematol. 1998;100:9-12 PMid:18574041

73. Gibson CS, MacLennan AH, Rudzki Z, Hague WM, Haan EA, Sharpe P, Priest K, Chan A, Dekker GA; South Australian Cerebral Palsy Research Group. The prevalence of inherited thrombophilias in a Caucasian Australian population. Pathology. 2005;37:160-163 PMid:9569177

74. Zoossmann-Diskin A, Gazit E, Peleg L, Shohat M, Turner D. Thrombophilic polymorphisms in Israel. Blood Cells Mol Dis. 2008;41:230-233 PMid:11434083

75. Rees DC, Chapman NH, Webster MT, Guerreiro JF, Rochette J, Clegg JB. Born to clot: the European burden. Br J Haematol. 1999; 105:564-566

76. Dilley A, Austin H, Hooper WC, El-Jamil M, Whitsett C, Wenger NK, Benson J, Evatt B. Prevalence of the prothrombin 20210 G-to-A variant in blacks: infants, patients with venous thrombosis, patients with myocardial infarction, and control subjects. J Lab Clin Med. 1998;132:452-455

77. Mack R, Chowdary D, Streck D, Dermody J. Inherited thrombophilia genes in minorities. Genet Test. 1999;3:371-373 PMid:21422408

78. Ruiz-Argüelles GJ, Garcés-Eisele J, Reyes-Núñez V, RamírezCisneros FJ. Primary thrombophilia in Mexico. II. Factor V G1691A (Leiden), prothrombin G20210A, and methylenetetrahydrofolate reductase C677T polymorphism in thrombophilic Mexican mestizos. Am J Hematol. 2001;66:28-31
79. Ruiz-Argüelles GJ, López-Martínez B, Valdés-Tapia P, GómezRangel JD, Reyes-Núñez V, Garcés-Eisele J. Primary thrombophilia in Mexico. V. A comprehensive prospective study indicates that most cases are multifactorial. Am J Hematol. 2005;78:21-26

80. Jun ZJ, Ping T, Lei Y, Li L, Ming SY, Jing W. Prevalence of factor V Leiden and prothrombin G20210A mutations in Chinese patients with deep venous thrombosis and pulmonary embolism. Clin Lab Haematol. 2006;28:111-116 PMid:18004248

81. Lu Y, Zhao Y, Liu G, Wang X, Liu Z, Chen B, Hui R. Factor V gene G1691A mutation, prothrombin gene G20210A mutation, and MTHFR gene C677T mutation are not risk factors for pulmonary thromboembolism in Chinese population. Thromb Res. 2002 1;106:7-12

82. Sakuma M, Shirato K. The epidemiology of acute pulmonary thromboembolism. Nihon Rinsho. 2003;61:1706-1712

83. Miyata T, Kawasaki T, Fujimura H, Uchida K, Tsushima M, Kato H. The prothrombin gene G20210A mutation is not found among Japanese patients with deep vein thrombosis and healthy individuals. Blood Coagul Fibrinolysis. 1998;9:451-452

84. Chang JD, Hur M, Lee SS, Yoo JH, Lee KM. Genetic background of nontraumatic osteonecrosis of the femoral head in the Korean population. Clin Orthop Relat Res. 2008;466:10411046

85. Kim YH, Kim JS. The 2007 John Charnley Award. Factors leading to low prevalence of DVT and pulmonary embolism after THA: analysis of genetic and prothrombotic factors. Clin Orthop Relat Res. 2007;465:33-39

86. Shen MC, Lin JS, Tsay W. Protein C and protein S deficiencies are the most important risk factors associated with thrombosis in Chinese venous thrombophilic patients in Taiwan. Thromb Res. 2000;99:447-452

87. Lin JS, Shen MC, Tsay W. The mutation at position 20210 in the 3 -untranslated region of the prothrombin gene is extremely rare in Taiwanese Chinese patients with venous thrombophilia. Thromb Haemost. 1998;80:343

88. Newton LJ, Krishnan A, Parapia LA. Born to clot: the European burden. Br J Haematol. 1999;107:213

89. Kumar SI, Kumar A, Srivastava S, Saraswat VA, Aggarwal R. Low frequency of factor V Leiden and prothrombin G20210A mutations in patients with hepatic venous outflow tract obstruction in northern India: a case-control study. Indian J Gastroenterol. 2005;24:211-215 PMid:16361766

90. Ghosh K, Shetty S, Madkaikar M, Pawar A, Nair S, Khare A, Pathare A, Jijina F, Mohanty D. Venous thromboembolism in young patients from western India: a study. Clin Appl Thromb Hemost.

2001;7:158-165 http://dx.doi.org/10.1177/107602960100700214 PMid:11292195

91. Angeline T, Bentley HA, Hawk AB, Manners RJ, Mokashi HA, Jeyaraj N, Tsongalis GJ. Prevalence of the Factor V G1691A and the Factor II/prothrombin G20210A gene polymorphisms among Tamilians. Exp Mol Pathol. 2005;79:9-13 http://dx.doi.org/10.1016/j.yexmp.2005.03.003 PMid:15896772

92. Garewal G, Das R, Ahluwalia J, Mittal N, Varma S. Prothrombin G20210A is not prevalent in North India. J Thromb Haemost. 2003;1:2253-2254 http://dx.doi.org/10.1046/j.15387836.2003.00430.x PMid:14521619

93. Bennett JA, Palmer LJ, Musk AW, Erber WN. Prevalence of factor V Leiden and prothrombin 20210A mutations in indigenous Australians. Thromb Haemost. 2001;86:1592-1593 PMid:11776339

94. Tamim H, Finan RR, Almawi WY. Prevalence of two thrombophilia predisposing mutations: factor V G1691A (R506Q; Leiden) and prothrombin G20210A, among healthy Lebanese. Thromb Haemost. 2002;.88:691-692

95. Finan RR, Tamin H, Amen G, Sharide HE, Rasid M, Alunen WY. Factor V G1691A and factor II G20210A mutations. Am J Hematol. 2002;71:300-305 http://dx.doi.org/10.1002/ajh.10223 PMid: 12447960

96. Sabbagh AS, Ibrahim G, Kanaan Z, Shammaa DM, Khalek RA, Ghasham M, Greige L, Mahfouz RA. Prevalence of the prothrombin G20210A polymorphism in the Lebanese population: use of a reverse hybridization strip assay approach. Mol Biol Rep. 2009;36:399-403 http://dx.doi.org/10.1007/s11033-007-9193-0 PMid:18066679

97. Bouaziz-Borgi L, Almawi WY, Mtiraoui N, Nsiri B, Keleshian 
SH, Kreidy R, Louzir B, Hezard N, Mahjoub T. Distinct association of factor V-Leiden and prothrombin G20210A mutations with deep venous thrombosis in Tunisia and Lebanon. Am J Hematol. 2006;81:641-643 http://dx.doi.org/10.1002/ajh.20582 PMid:16823828

98. Almawi WY, Keleshian SH, Borgi L, Fawaz NA, Abboud N, Mtiraoui N, Mahjoub T. Varied prevalence of factor V G1691A (Leiden) and prothrombin G20210A single nucleotide polymorphisms among Arabs. J Thromb Thrombolysis. 2005;20:163-168 http://dx.doi.org/10.1007/s11239-005-3550-4 PMid:16261289

99. Ameen G, Irani-Hakime N, Fawaz NA, Mahjoub T, Almawi WY. An Arab selective gradient in the distribution of factor $\mathrm{V}$ G1691A (Leiden), methylenetetrahydrofolate reductase (MTHFR) C677T. J Thromb Haemost. 2005;3:2126-2127 http://dx.doi.org/10.1111/j.1538-7836.2005.01546.x PMid:16102131

100.Dagan E, Brik R, Broza Y, Gershoni-Baruch R. HenochSchonlein purpura: polymorphisms in thrombophilia genes. Pediatr Nephrol. 2006;21:1117-1121 http://dx.doi.org/10.1007/s00467-006-0155-x PMid:16791607

101.Attia FM, Mikhailidis DP, Reffat SA. Prothrombin Gene G20210A Mutation in Acute Deep Venous Thrombosis Patients with Poor Response to Warfarin Therapy. Open Cardiovasc Med J. http://dx.doi.org/10.2174/1874192400903010147 PMid:19920886 PMCid:2778014

102. Mahjoub T, Mtiraoui N, Tamim H, Hizem S, Finan RR, Nsiri B, Almawi WY. Association between adverse pregnancy outcomes and maternal factor $\mathrm{V}$ G1691A (Leiden) and prothrombin G20210A genotypes in women with a history of recurrent idiopathic miscarriages. Am J Hematol. 2005;80:12-19 http://dx.doi.org/10.1002/ajh.20419 PMid:16138341

103.Mtiraoui N, Borgi L, Hizem S, Nsiri B, Finan RR, Gris JC, Almawi WY, Mahjoub T. Prevalence of antiphospholipid antibodies, factor V G1691A (Leiden) and prothrombin G20210A mutations in early and late recurrent pregnancy loss.
Eur J Obstet Gynecol Reprod Biol. 2005;119:164-170 http://dx.doi.org/10.1016/j.ejogrb.2004.07.003

104.Frere C, Saut N, Boukef MK, Zili M, Toumi NE. Factor V Leiden G1691A and prothrombin G20210A mutations are common in Tunisia. J Thromb Haemost. 2003;1:2451-2452 http://dx.doi.org/10.1046/j.1538-7836.2003.0468b.x PMid: 14629484

105.Klai S, Fekih-Mrissa N, Rachdi R, Gritli N. The status of thrombophilic defects and non-O blood group as risk factors for gestational vascular complications among Tunisian women. Acta Haematol. 2011;125:115-120 http://dx.doi.org/10.1159/000321934 PMid:21109732

106. Helley D, Chafa O, Yaker NL, Reghis A, Fischer AM. Prevalence of the prothrombin gene 20210A mutation in thrombophilic and healthy Algerian subjects. Thromb Haemost. 1999;82:1554-1555 PMid:10595654

107.Mathonnet F, Nadifi S, Serazin-Leroy V, Dakouane M, Giudicelli Y. Absence of factor $\mathrm{V}$ Leiden mutation and low prothrombin G 20210 A mutation prevalence in a healthy Moroccan population. Thromb Haemost. 2002;88:1073-1074 PMid:12529766

108.They-They TP, Hamzi K, Moutawafik MT, Bellayou H, El Messal M, Nadifi S. Prevalence of angiotensin-converting enzyme, methylenetetrahydrofolate reductase, Factor V Leiden, prothrombin and apolipoprotein $\mathrm{E}$ gene polymorphisms in Morocco. Ann Hum Biol. 2010;37:767-777 http://dx.doi.org/10.3109/03014461003738850 PMid:20687780

109. They-They TP, Battas O, Slassi I, Rafai MA, Katumbay DT, Nadifi S. Prothrombin G20210A and Factor V Leiden Polymorphisms in Stroke. J Mol Neurosci. 2011 [accepted for publication] http://dx.doi.org/10.1007/s12031-011-9580-9 PMid:21701789

110.Zivelin A, Rosenberg N, Faier S, Kornbrot N, Peretz H, Mannhalter C, Horellou MH, Seligsohn U. A single genetic origin for the common prothrombotic G20210A polymorphism in the prothrombin gene. Blood. 1998, 92(4):1119-24. PMid:9694698 